\title{
WASIAT: SOLUSI ALTERNATIF DARI PEMBAGIAN WARISAN YANG TIDAK ADIL?
}

\author{
Zaenul Mahmudi \\ Fakultas Syariah UIN Maulana Malik Ibrahim
}

\begin{abstract}
This article aims at conducting washiyyah institution as an alternative for distribution of inheritance as the verses of inheritance in Qur'an using the word washiyyah. It means that washiyyah has important position in the distribution of inheritance beside wârits institution. It is important for Muslim to use washiyyah institution replacing wârits one in the distribution of inheritance when he sees that the shares the Islamic law of inheritance system issues defy aginst principle of justice, the ultimate principle of Islamic teachings. Washiyyah institution consisting of specific justice for specific family is to be preferred than wârits institution consisting general one for general Muslim ummah.

Artikel ini bertujuan untuk mengkaji lembaga washiyyah sebagai alternatif pembagian kewarisan sebagaimana terminologi washiyyah dalam ayat-ayat Qur'an. Ini berarti bahwa washiyyah mempunyai posisi penting dalam pembagian warisan disamping lembaga wârits itu sendiri. Adalah penting untuk seorang Muslim menggunakan lembaga washiyyah menggantikan wârits dalam pembagian kewarisan ketika dia melihat bahwa persoalan system pembagian wârits hukum Islam bertentangan dengan prinsip keadilan, sebagai prinsip pokok dalam ajaran Islam. Lembaga washiyyah memuat keadilan khusus bagi keluarga tertentu yang perlu diprioritaskan dari pada lembaga wârits yang berlaku secara umum bagi umat muslim.
\end{abstract}

Kata kunci: Wasiat, Warits, Keadilan

Masyarakat Muslim Indonesia terperangkap dalam kondisi sulit ketika dihadapkan kepada permasalahan pembagian warisan. Dalam satu sisi, mereka ingin menerapkan Islam secara $k a f f a h$, termasuk dalam pembagian warisan, namun di sisi lain mereka merasakan ada "ketidakadilan" dalam pembagian warisan secara Islam (baca: Sunni) atau masyarakat lebih mengenalnya dengan sistem farâ'idl. Dilema tersebut terjadi karena prinsip dasar dalam pembagian warisan Islam adalah prinsip li al-dzakar mithl hadd al-unthayayn dalam konteks pembagian warisan antara ahli waris laki-laki dan perempuan ketika mereka berada pada derajat yang sama, seperti anak laki-anak perempuan; saudara laki-laki sekandung-saudara perempuan sekandung; saudara laki-laki seayah-saudara perempuan seayah; suami-isteri; dan ayah-ibu. Di mana perbandingan pembagian warisan $1: 2$ untuk perempuan dan laki-laki bertentangan dengan prinsip-prinsi universal, baik yang ada di legislasikan oleh Perserikatan Bangsa-Bangsa seperti Universal Declaration of Human Right (UDHR) dan Convention on Elimination of All Discrimination Against Women (CEDAW), maupun yang tercantum dalam Undang-Undang Dasar Republik Indonesia 1945 yang menegaskan tidak bolehnya melakukan diskriminasi atas dasar perbedaan jenis kelamin. 
Ratifikasi terhadap UDHR dan CEDAW ini memiliki konsekwensi bahwa pemerintah Indonesia memiliki kewajiban untuk menerapkan ketentuan-ketentuan yang diatur dalam UDHR dan CEDAW dalam peraturan perundangundangan di Indonesia, yaitu menghilangkan segala bentuk diskriminasi atas nama agama, jenis kelamin, suku dan lain-lain. Namun di sisi lain, para penjaga syariah yang direpresentasikan oleh para ulama, kiai, dan santri memiliki kepentingan untuk menjaga fikih waris tetap berada pada jalurnya. Mereka berpendapat bahwa ayat-ayat waris adalah ayat yang qath'î yang diperkuat dan dijustifikasi oleh kesepakatan ulama Sunni; Hanafi, Maliki, Syafi'i, dan Hanbali bahwa ketentuan warisan adalah sebagaimana yang terdapat dalam buku-buku hukum waris Islam.

Menanggapi pertentangan dalam pembagian warisan antara prinsip Islam dan prinsip universal ini Menteri Agama era Orde Baru, Munawir Sjadzali dalam proyek reaktualisasi ajaran Islam mengusulkan agar ada kesetaraan antara anak laki-laki dan anak perempuan dalam memperoleh warisan. Proyek reaktualisasi ini disampaikan dalam berbagai kesempatan sejak tahun 1985, ${ }^{1}$ baik di kalangan akademisi, ulama, maupun pesantren. Berdasarkan laporan yang diterimanya ketika menjadi Menteri Agama dari para hakim di daerah mengenai

Ceramah Munawir Sjadzali yang bertemakan "Reaktualisasi Ajaran Islam" atau "Dinamika Hukum Islam" ini pernah disampaikan dalam berbagai kesempatan, seperti dalam Seminar Hukum Islam IAIN Imam Bonjol, Padang; Bahts al-Masâ'il Syuriyah NU Jawa Timur di Tambak Beras Jombang; Seminar Kompilasi Hukum Islam oleh PP. Muhammadiyyah di Yogyakarta; Penataran Pemimpin Pemuda Ansor Seluruh Indonesia di Malang; Latihan Kader Tarjih Muhammadiyah di Yogyakarta; Ceramah di hadapan para mahasiswa Indonesia di Kairo; Forum Kodifikasi Hukum Islam yang diselenggarakan South East Asian Shariah Association di Kolombo, Srilanka; Jamuan Makanan yang diselenggarakan Menteri Pengajaran Malaysia, Anwar Ibrahim di Kula Lumpur. Dalam berbagai ceramah tersebut tidak ada tanggapan serius dari masyarakat, baru ceramah yang disampaikan dalam forum Paramadina mendapat tanggapan dan reaksi yang sangat serius dari masyarakat, lihat Munawir Sjadzali, "Reaktualisasi Ajaran Islam” dalam Polemik Reaktualisasi Ajaran Islam, Iqbal Abdurrauf Saimima (Peny.) (Jakarta: Pustaka Panjimas, 1988), 1 dan Munawir Sjadzali, Kontekstualisasi Ajaran Islam (Jakarta: Ikatan Persaudaraan Haji Indonesia (IPHI) dan Yayasan Wakaf Paramadina, 1995), h. 87-97. rendahnya tingkat ketaatan masyarakat Muslim dalam pelaksanaan ketentuan warisan yang diperkuat dengan pengalaman pribadinya, maka dia berkesimpulan bahwa ketentuan warisan Islam perlu dilakukan reaktualisasi agar lebih mencerminkan keadilan yang diinginkan masyarakat dengan pembagian warisan 1:1 untuk laki-laki dan perempuan.

Kondisi ini juga didukung oleh hasil penelitian disertasi di Universitah Padjadjaran Bandung yang dilakukan oleh Otje Salman pada tahun 1992 dengan judul "Pelaksanaan Hukum Waris di Daerah Cirebon Dilihat dari Hukum Waris Adat dan Hukum Waris Islam". ${ }^{2}$ Hasil penelitiannya menunjukkan bahwa masyarakat Muslim yang melakukan pembagian warisan sesuai ketentuan farấidl lebih sedikit dari pada mereka yang tidak. Mereka lebih merasa maslahah ketika membaginya dengan menggunakan institusi wasiat atau hibah.

Kondisi ini membuat prihatin masyarakat Muslim Indonesiasebagaimanayangdiungkapkan oleh Menteri Agama Orde Baru, Munawir Sjadzali yang mempertanyakan apakah prinip keadilan yang terdapat dalam sistem pembagian warisan secara farấidl sudah tidak sesuai lagi dengan kondisi masyarakat, sehingga banyak di antara mereka tidak mengimplementasikan sistem pembagian warisan tersebut dan beralih kepada institusi hibah dan wasiat dalam pembagian warisan dengan melakukan hîlah? Oleh karena itu, artikel ini bermaksud menguraikan apakah institusi wasiat bisa menggantikan posisi pembagian warisan secara farấidl?

\section{Konsepsi Wasiat}

Kata washiyyah merupakan bentuk mahdar dari washâ yang berarti mewasiatkan. Kata washiyyah yang sejatinya menunjukkan kepada perbuatan, namun kata ini sering merujuk kepada benda yang diwasiatkan (mûshâ bih). Sedangkan secara istilah, washiyyah adalah akad perpindahan hak milik, baik berupa harta maupun manfaat yang realisasinya dilakukan setelah meninggal dunia dengan tujuan dan

\footnotetext{
${ }^{2}$ Otje Salman, Kesadaran Hukum Masyarakat terhadap Hukum Waris (Bandung: Penerbit Alumni, 1993)
} 
cara yang baik. ${ }^{3}$

Secara historis, wasiat merupakan institusi pengalihan harta yang biasa dipraktikkan oleh bangsa-bangsa sebelum Islam. Hukum Romawi memberikan kebebasan kepada seorang pemilik harta untuk mewasiatkan hartanya kepada orang lain tanpa batas secara kuantitatif, bahkan dengan tidak menyisakan sama sekali untuk anak-anaknya. Bangsa Arab sebelum Islam merasa bangga dan berlomba-lomba memberikan wasiat kepada orang lain dan mengabaikan wasiat kepada para kerabatnya. ${ }^{4}$ Kondisi ini jelas merupakan kezaliman kepada anak-anak mereka dan kerabatnya yang lebih berhak untuk menerima harta milik orang tua atau kerabatnya daripada orang lain.

Ketika Islam datang, institusi wasiat sebagai media untuk pengalihan harta diluruskan dengan memberikan titik tekan terhadap wasiat kepada kedua orang tua dan para kerabatnya, sebagaimana dikemukakan dalam firman Allah:

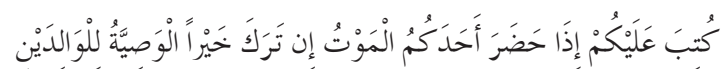

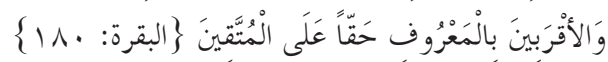

"Diwajibkan atas kamu, apabila seorang di antara kamu kedatangan (tanda-tanda) maut, jika ia meninggalkan harta yang banyak, berwasiat untuk ibu bapak dan karib kerabatnya secara makruf, (ini adalah) kewajiban atas orang-orang yang bertakwa. ${ }^{5}$

Dengan ayat ini, seorang pemilik harta diperintahkan untuk lebih mengutamakan wasiat kepada orang tua dan kerabatnya daripada orang lain dalam mendistribusikan harta miliknya. Dia boleh memberikan wasiat kepada orang lain apabila orang tua dan kerabatnya telah diberi wasiat terlebih dahulu.

Pengalihan harta antar generasi melalui institusi wasiat ini merupakan keniscayaan bagi pemilik harta sebelum ada institusi waris. Ketika seseorang yang memiliki harta dan merasa ajalnya telah dekat, dia diperintahkan

\footnotetext{
${ }^{3}$ Wuzârah al-Auqâf wa al-Syu'ûn al-Islâmiyyah, al-Mausû'ah al-Fiqhiyyah, Vol. 42 (Kuwait: Wuzârah alAuqâf wa al-Syu'ûn al-Islâmiyyah, 2004), h. 221

${ }^{4}$ Wahbah al-Zuhailî, al-Figh al-Islâmî wa Adillatuh, Vol. 8 (Damaskus: Dâr al-Fikr, 1985), h. 7

${ }^{5}$ Departemen Agama RI, al-Qur'an ..., h. 27.
}

membuat wasiat pengalihan harta kepada kedua orang tua dan kerabatnya agar harta yang ditinggalkan jatuh kepada orang-orang yang diinginkan dan berhak mendapatkan harta tersebut. Di sisi lain, wasiat harta ini akan memudahkan kepada keluarga yang ditinggalkan untuk mendistribusikan harta tersebut sesuai kehendak si mati, selain itu agar tidak terjadi perebutan harta yang rentan terhadap permusuhan antar keluarga di kemudian hari.

Menurut David S. Power institusi wasiat tersebut diberlakukan sebelum ayat waris turun di mana dia membuat periodesasi pengalihan harta antar generasi pada masa kenabian, yaitu:

a. Periode Mekkah (610-622M.), pada periode ini pengalihan harta antar generasi dilakukan dengan menggunakan institusi wasiat, sebagaimana yang biasa dilakukan oleh para sahabat seperti Bâdil ibn Maryam, seorang pedagang Quraisy dari Bani Sahm yang merasa akan meninggal ketika melakukan perjalanan dagang di Syiria yang kemudian berwasiat kepada dua orang mitra bisnisnya untuk menyerahkan hartanya kepada keluarganya di Mekkah. Demikian juga yang dilakukan oleh Aus ibn Tsâbit alAnshârî sebelum terbunuh ketika Perang Uhud di mana dia sempat berwasiat kepada dua orang sepupunya (anak laki-laki dari paman) untuk menyerahkan harta kepada keluarganya, namun kedua orang sepupu tersebut menolak untuk menyerahkan kepada isterinya, Ummu Kuhha' dan anakanak perempuannya. ${ }^{6}$

b. Periode Madinah Awal (622-630M.), pada periode ini institusi yang digunakan untuk mengalihkan harta antar generasi menggunakan institusi waris. Periode ini berkaitan erat dengan periode sebelumnya, khususnya mengenai perlakukan dua orang sepupu suami Ummu Kuhha, Aus ibn Tsâbit, yang tidak memberikan harta peninggalan suaminya kepada dirinya dan

\footnotetext{
6 David S. Powers, Studies in Qur'an and Hadith: The Formation of the Islamic Law of Inheritance (London: University of California Press, 1986), h. 10-11.
} 
anak-anak perempuannya. Permasalahan ini diadukan oleh Ummu Kuhha kepada Rasulullah saw. dan kemudian turun ayat waris yang pertama:

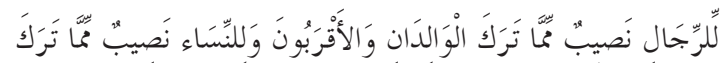

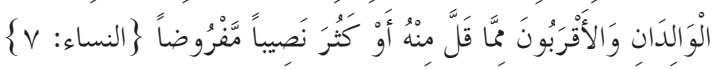

"Bagi laki-laki ada hak bagian dari harta peninggalan ibu bapak dan kerabatnya, dan bagi wanita ada hak bagian (pula) dari harta peninggalan ibu bapak dan kerabatnya, baik sedikit atau banyak menurut bagian yang telah ditetapkan"7

Kemudian ayat ini diikuti dengan ayatayat yang mengatur dan menentukan bagian warisan masing-masing ahli waris sebagaimana yang tercantum dalam surat al-Nisâ' ayat 11-12. ${ }^{8}$

c. Periode Setelah Fath Mekkah (630-632M). Pada periode ini tidak ada ketentuan pengalihan harta yang baru, namun periode ini mengatur keberlakukan dua institusi pengalihan harta; wasiat dan waris, yaitu pembatasan subyek yang boleh menerima wasiat dan pembatasan kuantitas wasiat yang hanya dibatasi maksimal sepertiga harta. ${ }^{9}$ Pertama, wasiat tidak boleh lagi diberikan kepada para ahli waris, sebagaimana sabda Rasulullah ketika menyampaikan khutbah pada waktu haji wada':

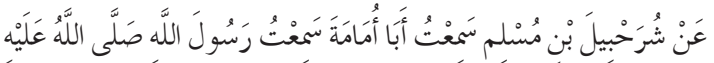

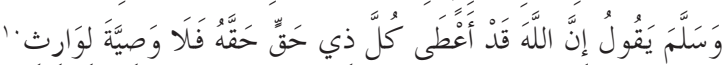

"Dari Syurahbîl ibn Muslim, saya mendengan Abû Umâmah berkata: saya pernah mendengar Rasulullah bersabda: Sesungguhnya Allah telah memberikan hak kepada setiap orang yang memiliki hak, maka dari itu tidak ada wasiat untuk ahli waris."

Ketentuanini diberlakukanuntuk menghindari penumpukan harta kepada orang tertentu saja (kay lâ yakûna dûlatan bayna al-aghniyấ) di mana apabila institusi waris dan wasiat sebagaimana

\footnotetext{
${ }^{7}$ Departemen Agama RI, al-Qur'an ..., h. 78

${ }^{8}$ David S. Powers, Studies..., h. 1

${ }^{9}$ Ibid, h. 13-14.

${ }^{10}$ Abû Dâwud Sulaimân al-Sijistânî al-Azdî, Sunan Ab̂̀ Dâwud, Vol. 3 (Beirut: Dâr Ibn Hazm, 1997), h. 196.
}

tetap diberlakukan secara bersamaan, maka orang tua; ayah dan ibu akan memperoleh bagian dari dua jalur, yaitu wasiat dan warisan. Penumpukan harta inilah yang tidak dikehendaki Islam dalam permasalahan pembagian harta.

Kedua, adalah ketentuan mengenai pembatasan jumlah wasiat yang diperbolehkan kepada orang selain ahli waris yang mendapatkan bagian warisan, sebagaimana sabda Rasulullah kepada Sa'd ibn Abi Waqâsh ketika berada di Mekkah saat menunaikan haji Wada':

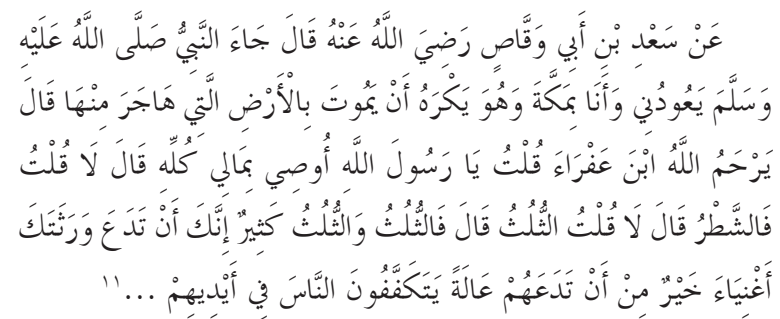

"Dari Sa'd ibn Abî Waqâsh ra. berkata: Nabi saw. pernah menjenguk saya ketika saya tinggal di Mekkah. Dia mengungkapkan ketidaksukaannya apabila meninggal dunia di wilayah di mana dia berhijrah seraya berkata: Semoga Engkau dirahmati oleh Allah, wahai Ibn 'Afrâ' (Sa'd ibn Abî Waqâsh). Kemudian saya bertanya kepada Rasulullah: Bolehkah saya mewasiatkan semua harta saya? Rasulullah menjawab: Jangan. Saya bertanya lagi: Bagaiamana apabila separuhnya? Dia menjazwab: Jangan. Saya bertanya kembali: bagiamana apabila sepertiganya? Dia menjawab: Sepertiga! Sepertiga itu banyak. Sesungguhnya apabila engkau meninggalkan para ahli warismu dalam kondisi kaya adalah lebih baik daripada engkau meninggalkan mereka dalam kondisi papa yang meminta-minta di hadapan orang-orang".

Berdasarkan kedua hadis di atas, maka institusi wasiat yang telah ada sebelum ketentuan-ketentuan al-Qur'an yang mengatur pembagian warisan (surat al-Nisâ' ayat: 7-13 dan 176) tidak dihapus secara total, namun ada pembatasan pemberlakuan wasiat tersebut, yaitu: tidak boleh wasiat kepada ahli waris dan wasiat kepada orang lain hanya diperbolehkan maksimal sepertiga harta. Ketentuan ini diberlakukan dalam rangka

${ }^{11}$ Abû 'Abdullâh Muhammad ibn Ismâ'îl alBukhârî, al-Jâmi' al-Shah hîh, Vol. 2 (Cairo: al-Mathba'ah al-Salafiyyah, 1403H.), h. 287 dan lihat juga Ibn Hajar al-'Asqalânî, Fath al-Bârî ...,Vol. 6, h. 674. 
lebih mengutamakan kepentingan anak-anak terlebih dahulu daripada kepentingan orang lain, sebagaimana yang diungkapkan dalam hadis di atas dan diperkuat firman Allah:

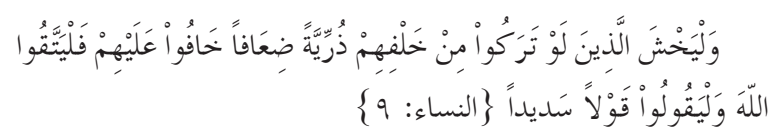

"Dan hendaklah takut kepada Allah orang-orang yang seandainya meninggalkan di belakang mereka anak-anak yang lemah, yang mereka khawatir terhadap kesejahteraan mereka. Oleh sebab itu, hendaklah mereka bertakwa kepada Allah dan hendaklah mereka mengucapkan perkataan yang benar". ${ }^{12}$

\section{Wasiat Perspektif KHI}

Hukum materil pengadilan yang digunakan dalam memutuskan perkara adalah Kompilasi Hukum Islam (KHI). KHI yang diberlakukan berdasarkan Intruksi Presiden No. 1 tahun 1991. KHI ini kedudukannya sangat lemah dalam tata hukum Indonesia karena KHI tidak tercantum dalam urutan perundang-undangan di Indonesia. Faktor-faktor yang memperkuat pemberlakuan KHI di Indonesia adalah: a) KHI merupakan kesepakatan ulama nusantara yang disimpulkan dari 38 buku fikih. ${ }^{13}$ Dan b) Keputusan Menteri Agama RI No. 154 Tahun 1991 tentang Pelaksanaan Instruksi Presiden RI No. 1 Tahun 1991 tanggal 10 Juni 1991 yang memerintahkan kepada suluruh instansi Departemen Agama dan instansi pemerintah terkait untuk menyebarluaskan KHI dan menerapkannya.

Permasalahan wasiat diatur pada Bab V masuk bagian dari Buku II yang mengatur tentang kewarisan yang diatur dalam pasal 194-209. Dalam ketentuan wasiat ini telah diatur beberapa rukun wasiat yang terdiri dari shîghat (îjâb dan qabûl), pewasiat (mûshin), penerima wasiat (mîsha lah), dan barang yang diwasiatkan (mûsha bih) ${ }_{1}^{14}$ yang masing-masing rukun-rukun tersebut diatur secara detail

\footnotetext{
${ }^{12}$ Departemen Agama RI, al-Qur'an...., h. 78

${ }^{13}$ Lihat Ahmad Imam Mawardi, "Socio-Political Background of the Enacment of Kompilasi Hukum Islam di Indonesia", Tesis, McGill University, Montreal, 1998, h. 16

${ }^{14}$ Wuzârah al-Auqâf, al-Mausû'ah..., Vol. 43, h. 226
}

dan dijelaskan dalam pasal-pasal, termasuk bagaimana melakukan wasiat, syarat-syarat yang harus dipenuhi dalam setiap rukun wasiat tersebut. Hal-hal pokok dalam wasiat dan kaitannya dengan waris adalah sebagai berikut:

a. Tentang cara berwasiat yang dalam Pasal 195 (1), Pasal 196 dan Pasal 199 di mana dalam ketiga pasal tersebut diatur mengenai cara berwasiat dan pencabutan wasiat yang hanya dilakukan dengan dua cara, yaitu dengan lisan di hadapan dua orang saksi atau tertulis di hadapan dua orang saksi atau notaris. Ketentuan ini menurut penulis tidak mengakomodir mereka yang tidak bisa bicara dan tidak bisa menulis sekaligus. Oleh karena itu, perlu diatur mengenai cara berwasiat bagi mereka yang memiliki kelemahan tersebut.

b. Tentang wasiat kepada ahli waris hanya berlaku apabila disetujui oleh semua ahli waris yang diatur dalam Pasal 195 (3). Dalam masalah ini, menurut penulis ada beberapa permasalahan, yaitu: a) pewaris sebagai pemilik harta seharusnya memiliki kekuasaan penuh terhadap harta yang dimilikinya, b) meminta persetujuan kepada semua ahli waris merupakan sesuatu yang tidak mudah, khususnya dalam keluarga yang tingkat ketaatan terhadap orang tua rendah, dan c) keadilan dalam pembagian wasiat tidak ditentukan dengan persamaan kuantitas, tetapi lebih ditentukan dengan jasa, relasi, dan tanggung jawab yang dipikul seseorang. Mereka yang memiliki jas a, relasi, dan tanggung jawab yang lebih besar dalam keluarga, layak mendapatkan bagian yang lebih banyak daripada yang lain dan hal ini hanya bisa dilakukan melalui hibah atau wasiat. Oleh karena itu, penulis mengusulkan untuk memilah-milah mengenai harta yang diwasiatkan, apabila harta tersebut merupakan harta pusaka, maka ketentuan pembagiannya berdasarkan hukum waris Islam, namun apabila harta tersebut merupakan hasil usahanya, maka pemilik harta tersebut memiliki kebebasan penuh dalam men-tasharruf-kan hartanya, 
meskipun tanpa persetujuan ahli waris.

c. Tentang wasiat pembagian harta kepada ahli waris. Wasiat seperti ini sering dilakukan oleh masyarakat, sehingga perlu ada pengaturan mengenai kebolehannya. Penulis mengusulkan untuk memberikan kebolehan terhadap wasiat seperti ini dengan syarat sebagian besar ahli waris setuju dengan wasiat orang tuanya, khususnya wasiat terhadap harta yang merupakan hasil usahanya.

\section{Wasiat sebagai Pengganti Waris}

Ada beberapa metode yang bisa digunakan untuk pengalihan harta antar generasi yang jamak dilakukan oleh masyarakat, yaitu hibah, wasiat, dan waris. Kedua institusi yang pertama; hibah dan wasiat sering dilakukan oleh masyarakat ketika orang tua merasa khawatir apabila pembagian warisan secara farâ'idl bisa berdampak kurang baik terhadap keutuhan dan kerukunan keluarga atau orang tua merasakan bahwa pembagian warisan secara farâ'idl kurang memenuhi rasa keadilan di keluarga mereka.

Praktik pembagianharta dengan menggunakan institusi hibah dan wasiat jamak terjadi di masyarakat. Ketika penulis yang juga dosen Fiqh Mawaris mempertanyakan kepada mahasiswa yang mengambil matakuliah tersebut, kurang lebih $80 \%$ mahasiswa mengatakan bahwa praktik pembagian harta tidak dilakukan sesuai dengan ketentuan farâidl, melainkan menggunakan hibah atau wasiat, khususnya wasiat pembagian harta warisan. Pada praktiknya, pemberian hibah dan wasiat juga bermacammacam. Ada yang membagi berdasarkan tingkat perekonomian "ahli waris", ada yang membagi dengan melebihkan bagian untuk anak laki-laki daripada anak perempuan, namun tidak persis dua berbanding satu, dan ada juga yang menghibahkan hampir semua hartanya secara sama antara laki-laki dan perempuan dan menyisakan sedikit harta warisan yang akan dibagi secara farâidl, ada yang memberikan hibah lebih banyak kepada anak perempuan dengan harapan ketika pembagian warisan secara farâidl nanti bagian anak laki-laki dan anak perempuan sama atau tidak berbeda jauh.

Kondisi ini juga didukung oleh hasil penelitian disertasi di Universitah Padjadjaran Bandung yang dilakukan oleh Otje Salman pada tahun 1992 dengan judul “Pelaksanaan Hukum Waris di Daerah Cirebon Dilihat dari Hukum Waris Adat dan Hukum Waris Islam". ${ }^{15}$ Responden yang diteliti dalam penelitian ini, dari sisi agama: $98,62 \%$ beragama Islam, sementara sisanya beragama non-Islam. ${ }^{16}$ Dari total responden, mereka yang melakukan pembagian warisan secara farâidl murni hanya berjumlah $26,5 \%$ sementara yang lain menggunakan hukum adat, hukum barat, atau percampuran antara berbagai hukum tersebut. ${ }^{17}$ Sementara mengenai kapan pelaksanaan pembagian harta tersebut: 45,45\% dilakukan ketika "pewaris" masih hidup dan $54,55 \%$ ketika "pewaris telah meninggal". ${ }^{18}$ Pembagian harta ketika pemilik harta masih hidup yang jumlahnya $45,45 \%$ tersebut berarti pembagian hartanya dilakukan dengan cara hibah, sedangkan pembagian harta ketika pemilik telah meninggal yang jumlahnya $54,55 \%$ berarti pembagiannya dilakukan dengan cara wasiat atau waris.

Dari penelitian tersebut, Otje Salman berkesimpulan bahwa ketaatan masyarakat Cirebon dalam melaksanakan hukum waris Islam adalah lemah, mereka lebih memilih penyelesaian dengan menggunakan hukumbarat daripada hukum Islam (farâ'idl), sementara itu pelaksanaan pembagian harta melalui intitusi waris lebih rendah daripada institusi hibah dan wasiat. Kondisi rendahnya kesadaran hukum terhadap pelaksanaan pembagian warisan secara Islam (farâ'idl) ini timbul karena dua kemungkinan, yaitu: (a) rendahnya sosialisasi kepada masyarakat mengenai hukum waris Islam dan (b) rendahnya pemahaman masyarakat terhadap hukum waris Islam.

Rendahnya tingkat ketaatan masyarakat dalam menerapkan ketentuan yang terdapat dalam farâidl ini, di samping yang disimpulkan

${ }^{15}$ Otje Salman, Kesadaran Hukum Masyarakat terhadap Hukum Waris (Bandung: Penerbit Alumni, 1993)

${ }^{16}$ Ibid, h. 92

${ }^{17}$ Ibid, h. 100

${ }^{18} \mathrm{Ibid}$, h. 99 
oleh Otje Salman tersebut, menurut Hazairin disebabkan oleh perbedaan kultur dan sistem kekeluargaan antara tempat diformulasikannya ketentuan waris Islam dengan Indonesia. Hukum waris Islam didasarkan kepada kebudayaan Arab yang bersendikan sistem kekeluargaan Patrilineal, ${ }^{19}$ sementara sistem kekeluargaan yang berkembang di Indonesia, mayoritas menganut sistem kekeluargaan bilateral atau parental, sesuai dengan sistem kekeluargaan yang dikehendaki dalam al-Qur'an. Sistem kekeluargaan dan sistem kewarisan Islam Sunnī (farâ'idl) yang tidak sinkron inilah yang mengakibatkan terjadi banyak konflik dalam penerapan hukum waris Islam di Indonesia, bahkan dalam keluarga yang menganut sistem kekeluargaan Patrilineal sekalipun.

Sementara dalam konteks penyelesaian perkara hibah, wasiat dan waris di Pengadilan Agama, Satria Efendi mengatakan banyak para hakim Pengadilan Agama yang tidak memahami sepenuhnya perkara hibah, wasiat dan waris dari sisi fiqihnya, sehingga berimplikasi kepada tidak terpenuhinya rasa keadilan yang diharapkan oleh para penggugat atau para tergugat sebagai pencari keadilan. ${ }^{20} \mathrm{Di}$ samping itu, hukum materiil yang digunakan juga, sebagian, mencampuradukkan antara Hukum Perdata dan Hukum Islam, dan bahkan lebih cenderung kepada Hukum Perdata. Selain itu, menurutnya ada kecenderungan hakim hanya berpedoman kepada teks-teks hukum yang terdapat dalam pasal-pasal peraturan yang dijadikan sumber hukum meteriil. Mereka kurang memperhatikan prinsip-prinsip keadilan yang menjadi tujuan dalam proses beracara dan penegakan hukum di pengadilan agama. Oleh karena itu, hakim perlu lebih fokus kepada penegakan keadilan daripada hanya fokus dan rigid kepada teks hukum karena teks hukum adalah media untuk mencapai tujuan, yaitu menegakkan keadilan.

${ }^{19}$ Hazairin, Hukum Kewarisan Bilateral Menurut Qur'an dan Hadith (Jakarta: Tintamas, 1976), h. 2

${ }^{20}$ Satria Effendi M. Zein, Problematika Hukum Keluarga Islam Kontemporer: Analisis Yurisprudensi dengan Pendekatan Ushuliyyah (Jakarta: Prenada Media, 2004)
Pertanyaan kemudian, apakah pembagian harta "warisan" dengan menggunakan institusi wasiat itu tidak diperbolehkan atau bertentangan dengan syariat Islam, mengingat sudah ada hukum waris untuk penyelesaian pembagian warisan? Bukankah ketika lari dari hukum waris Islam, berarti tidak mengakui keadilan hukum waris Islam? Guna menjawab permasalahan ini, ada baiknya melihat teks yang berkenaan dengan permasalahan wasiat dan waris dalam al-Qur'an. Ada beberapa hal yang perlu diperhatikan ketika melihat hubungan antara waris dan wasiat: a) ayat waris diawali dengan kata wasiat (يوصيكم الله في أولادكم) dan dikahiri dengan kalimat wasiat juga (وصية من الله والله (عليه حليه setelah pelaksanaan wasiat dimana terdapat empat versi kalimat

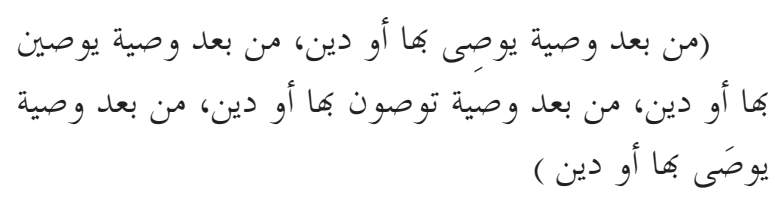

Berdasarkan ayat-ayat di atas, maka hubungan antara waris dan wasiat tidak bisa diabaikan, karena pertama, wasiat merupakan cikal-bakal pembagian harta peninggalan sebelum adanya institusi waris. David S. Power menegaskan bahwa institusi wasiat ini jamak dilakukan oleh masyarakat Muslim sebelum diturunkannya ayat pembagian warisan, sehingga pembagian harta peninggalan telah menjadi tradisi dan budaya masyarakat. Penulis berasumsi bahwa pembagian harta melalui institusi wasiat ini telah menjadi kesepakatan masyarakat ketika itu, termasuk siapa yang berhak menerima wasiat dan berapa bagian masing, namun karena institusi wasiat ini pada dasarnya siapa dan berapa besar bagian seseorang tersebut tergantung penuh kepada kehendak pemilik harta (al-mîshî) dan tidak ada ketentuan yang mengikat baginya, maka kemudian juga terjadi penyimpangan-penyimpangan yang menimbulkan kezaliman di masyarakat.

Kedua, ayat waris merupakan legitimasi dari Allah atas prektek-praktek pembagian wasiat;

${ }^{21}$ Muhammad Syahrûr, Nahrwa Ushûl Jadîdah li al-Figh al-Islâmî: Figh al-Mar'ah (al-Washiyyah, al-Irts, al-Qiwômah, al-Ta'adudiyyah, al-Libâs) (Damaskus: alAhâlî, 2000), h. 222. 
kepada siapa dan berapa besar bagiannya agar masyarakat Muslim ketika itu memiliki pegangan dan bagi mereka yang ingin berbuat zalim atas harta peninggalan tidak mudah melakukannya, karena telah ada aturan dan ketentuan yang tegas untuk siapa dan besar bagiannya berapa? Unifikasi hukum atas variasi pendistribusian wasiat dalam bentuk institusi waris ini penting untuk memberikan kepastian hukum kepada masyarakat, sehinggat tidak terjadi banyak versi pembagian wasiat. Dari sini dapat diketahui bahwa terdapat hubungan yang kuat antara wasiat dan waris, di mana wasiat merupakan prinsip awal pembagian harta peninggalan, sementara institusi waris merupakan legitimasi dan unifikasi yang diberikan Allah terhadap institusi wasiat.

Sementara apabila memperhatikan ayat waris yang menekankan kepada umat Islam untuk memperhatikan wasiat terlebih dahulu sebelum menunaikan wasiat (min ba'd washiyyat

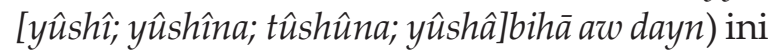
menunjukkan bahwa pembagian wasiat adalah lebih penting daripada waris. Syahrur menyatakan bahwa institutsi wasiat mereperesentasikan keadilan khusus, sementara institusi waris merupakan reprentasi keadilan umum.22 Orang tua (al-mûshî) adalah orang yang paling tahu siapa-siapa anaknya yang pantas mendapatkan harta darinya dan berapa bagiannya, ini yang dimaksud dengan keadilan khusus, yaitu keadilan yang berlaku khusus untuk keluarga atau masyarakat tertentu. Namun ketika tidak ada wasiat yang dibuat untuk anak-anaknya mengenai pembagian harta, maka berarti dia telah merelakan hartanya untuk dibagi berdasarkan keadilan umum yang tercantum dalam ayat-ayat waris.

Keadilan umum yang terdapat dalam ayat waris juga tidak bisa dilepaskan sepenuhnya dari konteks sosial waktu itu. Ketika institusi waris sebagai legitimasi dan unifikasi variasi model wasiat, maka sebenarnya yang perlu diperhatikan adalah ketentuan pokok yang ada pada institusi wasiat, di mana seorang $m \bar{u} s h \bar{\imath}$ memiliki kebebasan penuh mendistribusikan hartanya, di dalam benaknya adalah dia ingin

${ }^{22}$ Muhhammad Syahrûr, Nahwwa, h. 222-223. berbuat seadil-adilnya kepada anak-anaknya, di mana keputusan dan pilihan hukum yang ditetapkan tidak bisa dilepaskan dari konteks sosial di mana anak laki-laki memiliki tanggung jawab lebih daripada anak perempuan yang berimplikasi distribusi wasiat juga melebihkan bagian untuk laki-laki daripada perempuan yang pada gilirannya dilegitimasi oleh al$\mathrm{Qu}$ 'ran dalam ayat waris.

Dalam pembagian harta kekayaan termasuk harta warisan, prinsip utama yang harus dikedepankan adalah prinsip keadilan distributif artinya bahwa siapa orang yang berhak mendapatkan harta dan bagiannya berapa perlu didasarkan kepada tanggung jawab, jasa dan manfaat yang diberikan kepada pemilik harta. Keadilan merupakan prinsip utama syariah yang harus dijadikan pedoman dan tujuan dalam setiap penentuan hukum, sebagaimana yang dikatakan Ibn Qayyim alJauziyyah berikut:

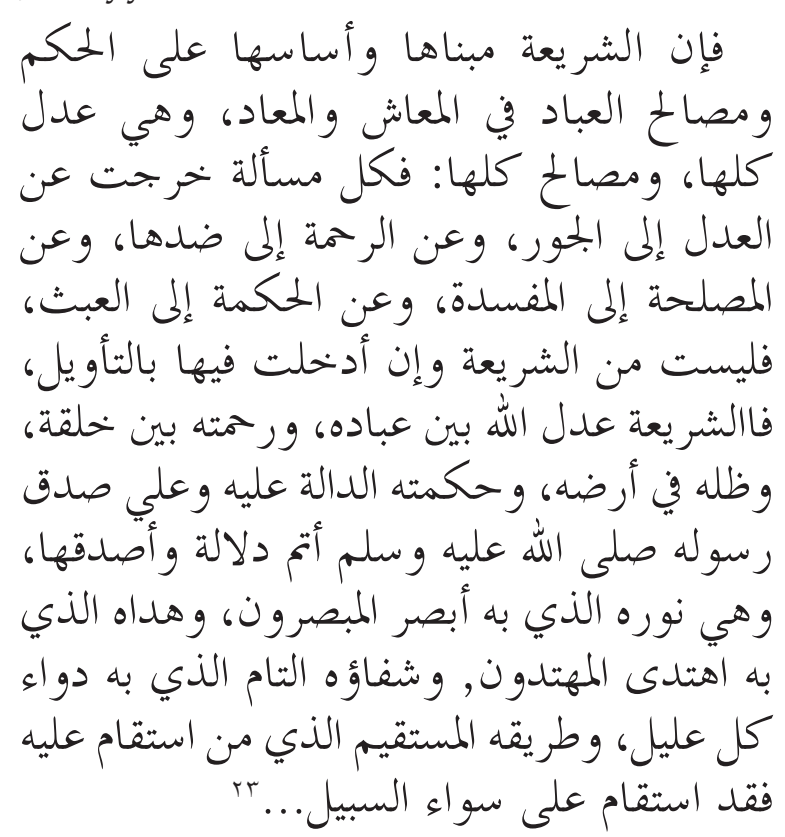

"Sesungguhnya syariah itu pondasi dan asasnya adalah kebijaksanaan dan kemaslahatan manusia di dunia maupun diakhirat. Syariah, secara keseluruhan adalah keadilan dan kemaslahatan. Setiap hal yang tidakmengedepankan keadilan, tetapi kelaliman; tidak mengedepankan kasih sayang, tetapi kebalikannya; tidak mengedepankan kemaslahatan, tetapi kerusakan;

${ }^{23} \mathrm{Ibn}$ Qayyim al-Jawziyyah, I'lâm al-Muwaqqi'în 'an Rabb al-'Âlamîn, Vol. 4. (Riyâd\}: Dâr Ibn al-Jawzî, 1423 H.), h. 337. 
tidak mengedepankan kebijaksanaan, tetapi kesiasiaan; maka semua itu bukan syariah, meskipun digali melalui ta'wîl. syariah adalah keadilan Allah yang dianugerahkan kepada para hamba-Nya, rahmat Allah yang dicurahkan kepada para makhluk-Nya; naungan Allah atas bumi Allah; dan hikmah Allah yang menunjukkan eksistensi-Nya dan kebenaran Rasulullah saw. sebagai petunjuk yang sempurna dan paling benar. Syariah adalah nûr Allah yang bisa menjadikan orang menjadi berpikir; petunjuk Allah yang membuat orang mendapatkan petunjuk; obat sempurna yang menjadi obat bagi segala penyakit; dan jalan Allah yang lurus yang bisa menjadikan orang beristiqamah kepada jalan yang lurus..."

Keadilan yang benar-benar dirasakan dalam pembagian harta warisan dalam keluarga tertentu tidak lebih bisa dirasakan dalam pembagian yang menggunakan institusi wasiat karena pembagian harta dalam institusi ini, seorang pemilik harta bisa menentukan siapa dan berapa bagian harta yang diberikan kepadanya. Artinya, keadilan dalam institusi wasiat bersifat khusus untuk keluarga tertentu yang tidak bisa digeneralisir kepada keluarga yang lain. Berbeda dengan institusi waris, di mana institusi ini pelaksanaannya adalah setelah ditunaikannya wasiat, artinya ketika tidak ada wasiat, maka berlakulah ketentuan waris sebagai keadilan umum di mana mayoritas umat Islam, khususnya masyarakat ketika sistem kewarisan Sunni diformulasikan.

Namun pemikiran ini merupakan pemikiran baru, di mana pada realitasnya masyarakat Muslim sekarang ini: (1) Memberikan prioritas secara mutlak kepada waris dan ketentuanketentuannya, bukan wasiat dan ketentuanketentuannya; (2) Menekankan kepada penghapusan ayat wasiat khususnya terhadap firman Allah: "al-washiyyatu li al-wâlidayn wa al-aqrabîn" dengan hadis ahad dan munqathi' yang diriwayatkan oleh ahl al-maghâzî "lâ washiyyata li wârits"; (3) Mencampur aduk pemahaman terhadap kata al-hadl dan al-nashîb yang berimplikasi kepada pencampuran antara ayat waris dan ayat wasiat. Firman Allah: (للرجال dianggap sebagai ayat waris, padahal ayat tersebut adalah ayat wasiat, karena nashîb adalah bagian manusia dalam wasiat, sementara hadd adalah apa yang diterimanya dalam waris; (4) Tidak membedakan antara keadilan umum yang terdapat dalam ayat waris dan keadilan khusus dalam ayat wasiat, di mana yang umum tidak boleh menutupi yang khusus. ${ }^{24}$

Syahrur merasa tidak sependapat terhadap pendapatmayoritasulamayang menomorduakan posisi wasiat setelah waris mengingat banyaknya penggunaan kata wasiat daripada waris dalam al-Qur'an. Artinya wasiat harus lebih diutamakan daripada waris, karena wasiat berisi keadilan khusus dalam pembagian harta "warisan" yang harus diprioritaskan daripada keadilan umum yang terdapat dalam ayat waris. Ketentuan wasiat inilah yang lebih bisa merealisasikan keadilan dalam pembagian "warisan" di masyarakat atau keluarga tertentu, mengingat setiap keluarga atau masyarakat memiliki relasi dan tanggung jawab dalam keluarga yang berbeda antara keluarga atau masyarakat satu dengan yang lain.

Oleh karena itu, perilaku masyarakat atau keluarga untuk melakukan pembagian "warisan" dengan menggunakan institusi hibah atau wasiat merupakan didorong oleh motif alamiah dalam rangka menegakkan keadilan dalam pembagian harta "warisan" yang disesuaikan dengan relasi dan tunggung jawab masing-masing individu dalam keluarga dan masyarakat yang tentunya memiliki perbedaan antara keluarga atau masyarakat satu dengan yang lainnya.

\section{Penutup}

Rendahnya tingkat ketaatan masyarakat Indonesia dalam menerapkan ketentuan yang terdapat dalam farâ'idl adalah disebabkan oleh perbedaan kultur dan sistem kekeluargaan antara tempat diformulasikannya ketentuan waris Islam dengan Indonesia. Hukum waris Islam didasarkan kepada kebudayaan Arabyang bersendikan sistem kekeluargaan Patrilineal, ${ }^{25}$ sementara sistem kekeluargaan yang dikehendaki dalam al-Qur'an adalah sistem kekeluargaan

\footnotetext{
${ }^{24}$ Muhammad Syahrûr, Naḩwa, h. 222-223.

${ }^{25}$ Hazairin, Hukum Kewarisan Bilateral Menurut Qur'an dan Hadith (Jakarta: Tintamas, 1976), h. 2
} 
parental atau bilateral. Tidak ada sinkronisasi antara sistem kekeluargaan dan sistem kewarisan ini yang menyebabkan terjadinya banyak konflik dalam penerapan hukum waris Islam di Indonesia, bahkan dalam keluarga yang menganut sistem kekeluargaan Patrilineal sekalipun.

Institusi waris Islam adalah hasil ijtihad para ulama yang dipengaruhi oleh kondisi sosial, ketika kondisi sosial berubah, tentunya hasil ijtihad juga berubah. Demikian juga institusi waris yang dirumuskan oleh para ulama dahulu mungkin sudah tidak sesuai lagi untuk diterapkan di Indonesia, mengingat terdapat perbedaan besar antara konteks Indonesia dan konteks ketika institusi waris

\section{DAFTAR PUSTAKA}

Abû Dâwud Sulaimân al-Sijistânî alAzdî, Sunan Abî Dâwud, Vol. 3/ Beirut: Dār Ibn ๑azm, 1997

Bukhârîal-, Abû 'Abdullâh Mu®ammad ibn Ismâ'îl, al-Jâmi' al-Shahîh hol. Vo, Cairo: al-Mathba'ah al-Salafiyyah, $1403 \mathrm{H}$

Departemen Agama RI, al-Qur'an dan Terjemahnya, Bandung: CV. Penerbit Jumanatul Ali Art, 2007

Hazairin, Hukum Kewarisan Bilateral Menurut Qur'an dan Hadith, Jakarta: Tintamas, 1976

Jawziyyah al-, Ibn Qayyim, I'lâm al-Muwaqqi în 'an Rabb al-'Âlaminn, Vol. 4, Riyâdl: Dâr Ibn alJawzî, $1423 \mathrm{H}$

Mawardi, Ahmad Imam, "Socio-Political Background of the Enacment of Kompilasi Hukum Islam di Indonesia", Tesis, McGill University, Montreal, 1998

Powers David S., Studies in Qur'an and Hadith: The Formation of the Islamic Law of Inheritance, London: University of California Press, 1986

Salman' Otje, Kesadaran Hukum Masyarakat terhadap Hukum Waris (Bandung: Penerbit dirumuskan, baik dari sisi waktu, tempat, budaya, perkembangan masyarakat maupun perkembangan teknologi.

Namun, merubah sesuatu yang telah mendarah daging di masyarakat bukan sesuatu pekerjaan yang mudah, apalagi ketentuah waris didukung ayat-ayat (yang katanya) qat'‘ yang tidak boleh dirasionalkan lagi. Oleh karena itu, kita perlu merivitalisasi institusi wasiat dan mengembalikannya sebagai dasar yang menjadi pondasi bangunan ketentuan dalam institusi waris. Kita harus merubah persepsi masyarakat yang menomorduakan wasiat daripada waris, tetapi wasiat harus lebih diprioritaskan daripada waris sebagaimana yang terdapat dalam al-Qur'an. Wallâh a'lam bi al-shawâb.

Alumni, 1993)

Sjadzali, Munawir, "Reaktualisasi Ajaran Islam" dalam Polemik Reaktualisasi Ajaran Islam, Iqbal Abdurrauf Saimima (Peny.), Jakarta: Pustaka Panjimas, 1988

Sjadzali, Munawir, Kontekstualisasi Ajaran Islam, Jakarta: Ikatan Persaudaraan Haji Indonesia (IPHI) dan Yayasan Wakaf Paramadina, 1995

Syahrur, Muøammad, Nahrwa Ushûl Jadîdah li al-Figh al-Islâmî: Figh al-Mar'ah (al-Washiyyah, al-Irts, al-Qiwâmah, al-Ta'adudiyyah, al-Libâs), Damaskus: al-Ahâlî, 2000

Wuzârah al-Auqâf wa al-Syu'ûn al-Islāmiyyah, al-Mausû'ah al-Fiqhiyyah, Vol. 42, Kuwait: Wuzârah al-Auqâf wa al-Syu' ūn al-Islāmiyyah, 2004

Zein, Satria Effendi M., Problematika Hukum Keluarga Islam Kontemporer: Analisis Yurisprudensi dengan Pendekatan Ushuliyyah (Jakarta: Prenada Media, 2004)

Zuhailî al-, Wahbah, al-Figh al-Islâmî wa Adillatuh, Vol. 8, Damaskus: Dâr al-Fikr, 1985 